\title{
In-vivo Hepatoprotective Activity of Methanolic Extracts of Sphaeranthus amaranthoides and Oldenlandia umbellate
}

\author{
Somnath $\mathrm{De}^{1 *}$, Ramalingam Suresh ${ }^{2}$, Akula Murali Sri Sudhakar Babu ${ }^{3}$, Siddabathuni Aneela ${ }^{1}$
}

\section{Somnath $\mathrm{De}^{1 *}$, Ramalingam} Suresh ${ }^{2}$, Akula Murali Sri Sudhakar Babu' ${ }^{3}$, Siddabathuni Aneela ${ }^{1}$ 'Samuel George Institute of Pharmaceutical Sciences, Markapur- 523316, Andhra Pradesh, India

${ }^{2}$ Annamalai University, Department of Pharmacy, Annamalai Nagar-600 802,

Tamil Nadu, India

${ }^{3}$ A.M. Reddy Memorial Colleges of Pharmacy, Narasaraopet, Guntur-522601,

Andhra Pradesh

\section{Correspondence}

Somnath De

Dr. Samuel George Institute of Pharmaceutical Sciences, Markapur-523316, Tarlupadu road, Andhra Pradesh, India.

Phone: +91-8596-224045, 9618347303

E-mail: somnath.bankura@gmail.com

History

- Submission Date: 18-09-2016:

- Review completed: 08-11-2016;

- Accepted Date: 08-11-2016.

DOI : 10.5530/pj.2017.1.16

Article Available online

http://www.phcogj.com/v9/i1

\section{Copyright}

(C) 2016 Phcog.Net. This is an openaccess article distributed under the terms of the Creative Commons Attribution 4.0 International license.

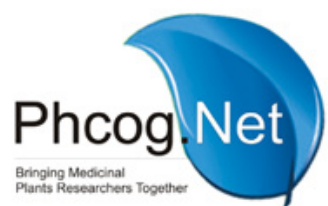

\begin{abstract}
Objective: The present study was carried out to evaluate the in vitro hepatoprotective activity of unexploited plants, Sphaeranthus amaranthoides and Oldenlandia umbellate on $\mathrm{CCl}_{4}$ induced liver injury, which are indigenous to South India. Methods: in the present study the methanolic extracts from Sphaeranthus amaranthoides and Oldenlandia umbellata were studied against the carbon tetrachloride hepatotoxicity. Results: significant hepatoprotective effect was obtained against carbon tetrachloride induced liver damage as judged from serum marker enzyme activities (SGOT, SGPT, ALT, and TB) and a normal architecture of liver compare to toxic control. Conclusion: the result revealed that methanolic extracts of Sphaeranthus amaranthoides and Oldenlandia umbellata could be useful in preventing $\mathrm{CCl}_{4}$ induced liver injury.

Key words: Hepatoprotective activity, Sphaeranthus amaranthoides, Oldenlandia umbellata, CCI, $\mathrm{SGOT,} \mathrm{SGPT,}$ ALP, TB.
\end{abstract}

\section{INTRODUCTION}

Liver is the largest and most complex internal organ in the body. It plays an important role in maintenance of internal environment with the help of its multifarious and several functions. It is connected to inter mediatory metabolism of proteins, fats, and carbohydrates as well as in the synthesis of number plasma proteins such as albumin, fibrinogen and in the production of various enzymes, formation and excretion of bile.

Drug-induced liver injury is a major health problem that remonstrance not only health care profession but also pharmaceutical industry and drug regulatory agencies. According to the United States Acute Liver Failure study group, drug-induced liver injury accounts for more than $50 \%$ of acute liver failure, including hepatotoxicity caused by overdose of acetaminophen (39\%) and idiosyncratic liver injury triggered by other drugs (13\%). ${ }^{1}$ Liver diseases have become one of the major causes formorbidity and mortality in man and animals all over globe and hepatotoxicity due to drug appears to be the most common contributing factors. ${ }^{2}$ Among the many diseases that can affect the liver that is "Viral Hepatitis "(inflammation of liver caused by viral infection). Hepatitis can be caused by the drugs, viruses, bacteria, mushrooms, parasite like moebas or giardiasis. In India about 40 poly herbal commercial formulations reputed to have hepatoprotective action are being used. It has been reported that 160 phyto constituents from 101 plants have hepatoprotective activity. ${ }^{3}$ Liver protective herbal drugs contain a variety of chemical constituents like phenols, coumarins, lignans, essential oil, monoterpenoids, carotenoids, glycosides, and xanthines. Plant extracts of many crude drugs are also used for the treatment of liver disorders. Extracts of different plants of about 25 plants have been reported to cure liver disorders. ${ }^{4}$
S.amaranthoides Burm. Is a small herb decumbent herb, with stem rooting and pubescent with exploited hair leaves palmately 3- foliolate. Features of the herb: low annual with spreading branches, stem e erect, glabrous, sometimes as thick as the little finger, but short, branches e not winged and 8-12 inches, leaves of 2-4 inches, linear, oblong narrowed at the base. This plant is well known for its medicinal value for the treatment of eczema, blood disorder, stomach warms, and filarial fever and as a remover of kapha, vata and piles. It is also known to cure the skin diseases. ${ }^{5}$ S.amaranthoides belongs to Plant kingdom, Dicotyledon class, Gamopetale sub class, Inferae series, Asterales order, and Astracea (compositae)family. It is weed of paddy field of southern India. The genus O. umbellate (family Rubiaceae) consists of different species, many of which are used in traditional medicine. ${ }^{6}$ O. umbellate is commonly known as Indian madder, known to yield a color-fast red dye from its roots and has been used in diverse applications since ancient times. The root bark, preferably of a 2 year old plant, when used with a mordant will confer red color to calico, wool, and silk fabrics. ${ }^{7}$

There is growing interest in herbal medicines because of their effectiveness, minimal side effects in clinical experience and relatively low cost. Herbal drugs or their biological active compounds are unknown.

Therefore, studies with plant extracts are useful to know their efficacy and mechanism of action and safety. Natural remedies from medicinal plant are considered to be effective and alternative treatment for hepatotoxicity.

\section{MATERIALS AND METHODS}

Plant Materials and Extraction:

The plants S. amaranthaoids (entire plant) and O. umbellate (entire plant) were col- 
lected from the Thoothukudi district, Tamilnadu, India, voucher. No. SGIP, Ref.no: 007 and 010 in the month of December 2011 and authenticated by Dr. V. Chelladurai, retired research officer - Botany, central council for research in Ayurveda and siddha (CCRAS), government of India; Tiruneveli . Herbarium of the plants was prepared and preserved in the department of pharmacognasy, Dr. Samuel George Institute of Pharmaceutical Sciences, Markapur, Prakasam district, Andhra Pradesh. Plant materials were air dried in the laboratory for 5 days at room temperature then grinded to powder form using an electrical mill. The powder sample was kept in an air tight container until required. About $100 \mathrm{~g}$ of each plant sample was extracted with $500 \mathrm{~mL}$ methanol solvent by using soxhlet extractor. After extraction the sample was kept in dark for 72 horus with intermittent shaking. Then both the solvents were evaporated under reduced pressure using Rota-Vapor and to obtain viscous semisolid masses.

\section{Phytochemical screening}

The preliminary phytochemical screening was carried out by methanolic extrac of both the plants for the presence of phyto constituents. The methanolic extract of both the plants were tested for steroids, alkaloids, phenolic compounds, flavonoids, saponins, tannins, anthraquinone and amino acids. Phytochemical screening of both the extracts was carried out according to the standard methods. ${ }^{8}$

\section{Acute Toxicity Studies}

The acute toxicity studies for methanolic extracts of both the plants were determined on albino mice (20-30g) the plants were determined on albino rat, maintained under standard condition. The animals were fasted overnight prior to the experiment. Fixed dose method as per OECD Guideline No. 425 method, given by CPCSEA was adopted for toxicity studies. ${ }^{9}$ the study was conducted by prior permission of institutional animal ethical committee (IAEC registration no. 1048/a/07/CPCSEA, approval no. 22/IAEC/CIPS/2014-15). The mice were divided in to control and test group each containing 6 animals. The test groups of mice were administrated with the dose of 25, 200, 500, 2000 and $5000 \mathrm{mg} / \mathrm{kg}$ of extracts. Carefully observe all the mice and any sign of toxicity in the first four hours, after the administration of extracts and daily following that for the period of 14 days.

\section{Hepatoprotective activity}

Selection of animals, caring and handling

The albino rats (wistar strain 150-200 g) of either sex were used. After randomization in to various groups, animals were accustomed for a period of 10 days under standard husbandry condition.

Room temperature: $23 \pm 3^{\circ} \mathrm{C}$

Relative humidity: $50 \pm 20 \%$

12 hrs dark and light cycle.

All the animals were feed with rodent pellet diet and water was allowed ad-libitum under strict hygienic condition. Ethical clearances for performing experiments on animals are obtained from Institutional Animal Ethical Committee (IAEC registration no. 1218/a/08/CPCSEA, approval no. 17/IAEC/SGIP/2014-15). The animals were divided in to vehicle control, toxic standard and test extract of S.amaranthoides $50 \mathrm{mg} / \mathrm{kg}$, S.amaranthoides $100 \mathrm{mg} / \mathrm{kg}$, and $O$. umbellate $50 \mathrm{mg} / \mathrm{kg}$, O. umbellate $100 \mathrm{mg} / \mathrm{kg}$ groups. Each consisting of 6 animals in all sets of experiments respectively. The drug treatment was given once daily per oral.

\section{Study designing and experimental protocol}

Albino rats of westar strain weighing 150-200 g were selected and divided in to 7 groups of each containing 6 animals. 5\% gum acacia was used as a vehicle control for suspending the standard drugs and the extracts. Vehicle control (group-I) received vehicle aqueous 5\% gum acacia. Group-II to Group-VII is administrated with $\mathrm{CCL}_{4}$ for 7 days at a dose of $0.25 \mathrm{ml} / 100 \mathrm{~g}$. Whereas the Group-II received only $\mathrm{CCL}_{4}$, Group-III receive the standard drug silymarin at a dose of $25 \mathrm{mg} / \mathrm{kg}$ b.w and Group-IV received MESA (Methanolic extract of $S$. amaranthoides) at a dose of $50 \mathrm{mg} / \mathrm{kg}$ b.w., Group- V received MESA (Methanolic extract of S. amaranthoides) at a dose of $100 \mathrm{mg} / \mathrm{kg}$ b.w., Group-VI received MEOU (Methanolic extract of O. umbelleta) at a dose of $50 \mathrm{mg} / \mathrm{kg}$ b.w., Group-VII received MEOU (Methanolic extract of O. umbelleta) at a dose of $100 \mathrm{mg} / \mathrm{kg}$ b.w. The vehicle control and all test extract administered orally for seven days at different dosage from level and enhance the liver damage in animals. On the $7^{\text {th }}$ day after 6 hrs of the administration

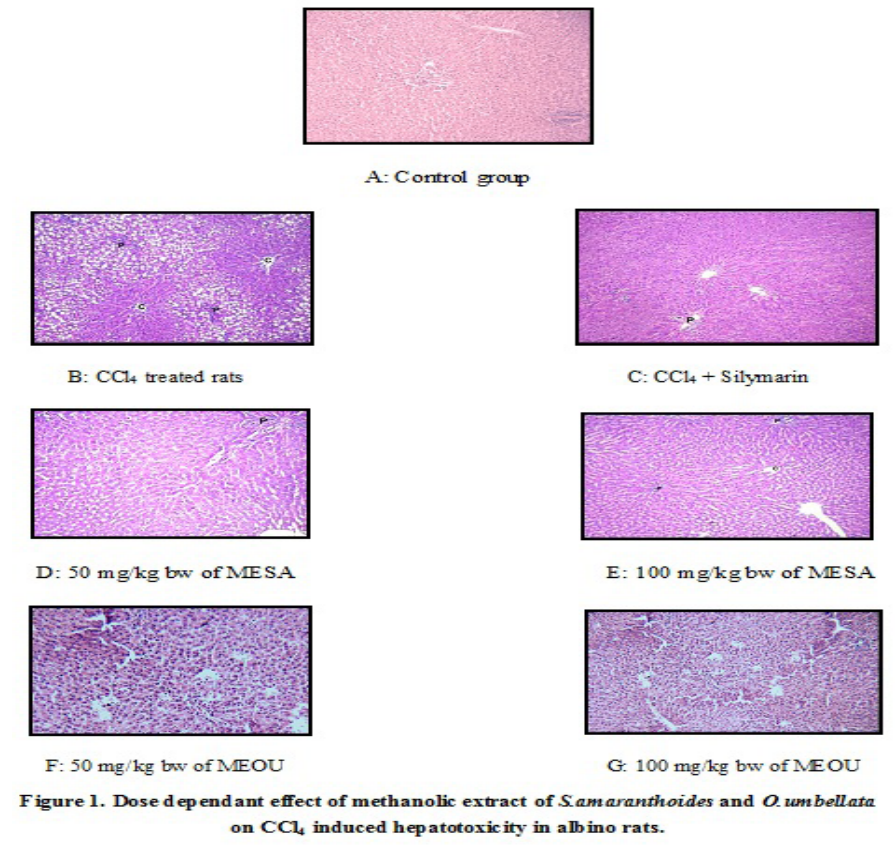




\begin{tabular}{|c|c|c|c|c|c|}
\hline SL.No & Groups & SGOT (IU/L) & SGPT (IU/L) & ALP (IU/L) & $\begin{array}{l}\text { Total bilirubin ( } \mathrm{mg} / \\
\mathrm{dl})\end{array}$ \\
\hline 1 & Control (group-I) & $119 \pm 2.82$ & $101.0 \pm 2.20$ & $187.97 \pm 1.6$ & $1.58 \pm 0.14$ \\
\hline 2 & Toxic control (group-II) & $353.16 \pm 8.79^{* *}$ & $394.82 \pm 3.14^{* *}$ & $444.36 \pm 7.88^{\star *}$ & $4.61 \pm 0.23^{\star *}$ \\
\hline 3 & $\begin{array}{l}\text { Standard group-III } \\
(25 \mathrm{mg} / \mathrm{kg})\end{array}$ & $124.86 \pm 3.39^{*}$ & $123.66 \pm 1.83^{*}$ & $184.81 \pm 2.05^{\star}$ & $2.05 \pm 0.03^{*}$ \\
\hline 4 & $\begin{array}{l}\text { M.E.S.A. group-IV (50 } \\
\mathrm{mg} / \mathrm{kg})\end{array}$ & $352.81 \pm 2.10^{*}$ & $328.28 \pm 1.99^{*}$ & $417.94 \pm 1.97^{*}$ & $3.28 \pm 0.028^{*}$ \\
\hline 5 & $\begin{array}{l}\text { M.E.S.A. group-V (100 } \\
\mathrm{mg} / \mathrm{kg})\end{array}$ & $319.14 \pm 4.25^{*}$ & $338.14 \pm 2.64^{\star}$ & $394.12 \pm 3.36^{*}$ & $3.07 \pm 0.18^{*}$ \\
\hline 6 & $\begin{array}{l}\text { M.E.O.U. group-VI (50 } \\
\mathrm{mg} / \mathrm{kg})\end{array}$ & $217.48 \pm 1.84^{*}$ & $216.45 \pm 3.98^{*}$ & $226.32 \pm 2.09^{*}$ & $2.64 \pm 0.3^{*}$ \\
\hline 7 & $\begin{array}{l}\text { M.E.O.U. group-VII } \\
(100 \mathrm{mg} / \mathrm{kg})\end{array}$ & $193.22 \pm 3.30^{*}$ & $211.43 \pm 2.42^{*}$ & $204.40 \pm 3.29$ & $2.33 \pm 0.02^{\star}$ \\
\hline
\end{tabular}

Values are mean $\pm \mathrm{SEM}, \mathrm{n}=6 .{ }^{* *} \mathrm{p}<0.01$, when compared with control group, ${ }^{*} \mathrm{p}<0.01$, when compared with toxic group

of the drug by giving a single dose of $\mathrm{CCl}_{4}$ with liquid paraffin (1: 1 ratio). After 24 hrs blood samples were drawn from all animals by puncturing retro-orbital plexus on the day of the treatment. The blood samples were centrifuged immediately to get clear serum and subjected for estimation of various biochemical parameters namely SGPT (serum glutamic pyruvic transaminase), SGOT (serum glutamic oxaloacetic transaminase), ALP (alkaline phosphate), and TB (total bilurubin). ${ }^{10-15}$ Later the animals were sacrificed and liver tissues were collected from all groups for histopathological studies. ${ }^{16}$

\section{Statistical Analysis}

Results were expressed as mean $<\mathrm{SEM}, \mathrm{n}=6$. Statistical analysis was performed with one way analysis of varience (ANOVA) by Dunnett's multiple comparisions test. $\mathrm{P}$ value $<0.01$ was considered to be statistically with control and toxicant group as possible.

\section{RESULT}

The present study had been attempted to demonstrate the role of hepatoprotective activity of crude methanol extracts of plant materials of S.amaranthoids and O. umbellate, belonging to the different family in $\mathrm{CCL}_{4}$ induced hepatotoxicity at different doses. The methanolic extract of both the plants are having same phytoconstituents after prior preliminary phytochemical test but here, the difference was found to be presence of anthraquinone in O.umbellate when compared with S.amaranthoids. In wellness parameter analysis no significant changes were observed for evolution toxicity. Skin, furr, eyes, mucous membrane, behavioral pattern, salivation, sleep of the treated as well as control animals were found to be normal. Tremor, lethargy, diarrhea and coma did not occur any of the animals. There was no significant damage of the liver and no significant structural changes detected in kidney, lung, and brain from all groups of the study. Carbon tetrachloride in one of the most potent hepatotoxic (toxic to the liver), and is widely used in scientific research to evaluate hepatoprotective agents. ${ }^{17}$ The result of the present study showed that, the level of SGOT [353.16 \pm 08.79] IU/L, SGPT $[394.82 \pm 03.14] \mathrm{IU} / \mathrm{L}, \mathrm{ALP}[444.36 \pm 07.88] \mathrm{IU} / \mathrm{L}$ and TB [4.61 \pm 0.23$]$ $\mathrm{mg} / \mathrm{dL}$ were significantly increased in toxic control treated group $(\mathrm{P}<0.01)$ (Group-2) when compared with control group. Administration of (50 and $100 \mathrm{mg} / \mathrm{kg}$ b.w.) both S. amaranthoids and O. umbellate extracts treated rats showed significant reduction level of SGOT,SGPT,ALP,TB $(\mathrm{P}<0.01)$ when compared with toxic treated rats. But the maximum reduction of SGOT $(319.74 \pm 04.25)$ and $(193.22 \pm 03.30)$ IU/L., SGPT
(338.14 \pm 02.64$)$ and $(211.43 \pm 02.42)$ IU/L., ALP $(394.12 \pm 03.36)$ and $(204.40 \pm 03.29) \mathrm{IU} / \mathrm{L} ., \mathrm{TB}(3.07 \pm 0.18)$ and $(2.33 \pm 0.02) \mathrm{mg} / \mathrm{dL}$ were observed in the high dose group $(100 \mathrm{mg} / \mathrm{kgb.w})(\mathrm{P}<0.01)$ (Table 1). Histopathological sources revealed that the maximum level of fatty changes, focal necrosis, and congestion in central vein and congestion sinusidal spaces were found in hepatotoxin treated rats. However S.amaranthoids and O. umbellate plant extracts $(50 \mathrm{mg} / \mathrm{kg}$ b.w and 100 $\mathrm{mg} / \mathrm{kg} \mathrm{b.w)} \mathrm{pretreated} \mathrm{rats} \mathrm{showed} \mathrm{reduction} \mathrm{in} \mathrm{fatty} \mathrm{changes} \mathrm{and} \mathrm{focal}$ necrosis, hydrophine changes. No visible changes (Figure-1) were observed.

\section{DISCUSSION}

The present study was revealed hepatoprotective activity in rats against $\mathrm{CCL}_{4}$ hepatotoxin to prove its claims in folklore practice against liver disorders. A number of reports indicate that overdose $\mathrm{CCL}_{4}$ can produce centrizonal hemorrhogie hepaticnecrosis in human and experimental animals ${ }^{18,19}$ Based on the result of acute oral toxicity studies for methanolic extracts of both the plants (S.amaranthoids and O.umbellate) would be rewarded as safe. There was no mortility found out during experimental periods of the animals. $\mathrm{CCL}_{4}$ induced hepatic injury is commonly used as an experimental method for the study of hepatoprotective effects of medicinal plants extracts. The extent of hepatic damage is assessed by histological evolution level of various biochemical parameters in circulation. $\mathrm{CCL}_{4}$ undergoes hepatic metabolism to give rise tri chloro methyl radicals, which upon reacting with reactive oxygen species yields tri chloro methyl peroxide radicals. These forms covalent bond with lipids and destroy the membrane integrity. It produces hepatotoxicity by altering liver microsomal membranes in experimental animals. From the table-1 it was evident that both the extracts (MESA AND MEOU) were able to reduce all the elevated biochemical parameters in the hepatotox in intoxication model. The reduction is attributed to the initial damage produced and localized in the endoplasmic reticulum which results in the loss of P450. Reduction in the levels of SGOT, SGPT, ALP and TB towards the noramal value is an indication of regeneration process. The histological examination of the liver sections revealed that the normal liver architecture was disturbed by hepatotoxin intoxication. In the liver sections of the rats treated with extracted and intoxicated with $\mathrm{CCL}_{4}$, the normal cellular architecture was retend as compared to silmyrin. ${ }^{20}$ thereby confirming the protective effect of both the extracts. The methanolic extract of S.amaranthoids and O.umbellate have shown very 
significant hepatoprotection against $\mathrm{CCL}_{4}$ induced hepatotoxicity in albino rats in reducing SGOT, SGPT, ALP and TB levels. Liver sction of S.amaranthoids and O.umbellate treated animal groups clearly showed normal hepatic cells thereby confirming hepatoprotective activity.

\section{CONCLUSION}

In conclusion, the precious information regarding acute oral toxicity profile of both the plants would be crucial for various pharmacological screening. On the other hand methanolic extract of S.amaranthoids and O.umbellate could be an important source of hepatoprotective compounds specifically for $\mathrm{CCL}_{4}$ induced hepatotoxicity.

\section{ACKNOWLEDGEMENT}

The authors are grateful to the Management of Dr.S.G.I.P.S, Markapur for providing necessary facilities to carry out the work and also gratifying to the Principal and Staff, Dr.S.G.I.P.S for their assistance with the study.

\section{CONFLICT OF INTEREST}

Authors declare that they have no competing interest.

\section{REFERENCES}

1. Holt MP, Cynthia JU. Mechanism of drug-induced liver injury. The AAPS Journal. 2006;8(1):48-54.

2. Nadeem MPC, Dandiya PC, Pasha M, Imran D, Balani K, Vohora SB. Hepatoprotective activity of Solanum nigrum fruits. Fitoterapia. 1997;68(3):245-51.

3. Handa SS, Sharma A, Chakraborti KK. Evolution of Indian herbal Hepatoprotective Drugs. Fitoterpia. 1986;57(5):307-51.

4. Sharma SK, Ali M, Guptha J. Hepatoprotective activity of aqueous ethanolic extract of chamomile capitula in paracetamol induced albino rats. Phytochemistry and Pharmacology. 2002;2:253-70.

5. Kirtikar KR, Basu BD. Indian medicinal plants, $2^{\text {nd }}$ edition volume-3.Deharadun:
Beshen Singh and Mahandra Pal Singh. 1971:2327-8.

6. Seydal P, Dornenburg H. Establishment of in-vitro plants. Cell and tissue cultures from 0 . affinis for the production of cyclic peptides. Plant cell Tiss. Org. Cult. 2006;85(3):247-55. http://dx.doi.org/10.1007/s11240-005-9056-0

7. Siva R. Status of natural dye and dye yielding plants in India. Curr Sci., 2007;92(7):916.

8. Brindha P, Sasikala B. Purushothaman KK. Pharmacological studies on Merugan Khizhangu. Bull Medico Ethnobot Res. 1981;3:84-96.

9. Prema Veeraghavan. Expert consultant, CPCSEA, OCED Guideline No. 425.

10. Teitz NW, Expert Panel on enzyme of the IFCC. Clin Chem Acta. 1976;70.

11. Teitz NW, Rinker D and Show LM. IFCC Method for alkaline phosphate. J. Clin. Chem. Clin Biochem I. 1983;21:731-48.

12. Burtis CA, Ashwood ER. Eds. Tietz Textbook of Clin Chem. Philadelphia. W.B Sunders Co. 1990;3:1829.

13. Teitz NW, Textbook of Clin Chem. Gambino, Michealson SR, Gambino MSR, Jama, W.B. Sunders Co. 1983;1834.

14. Teitz NW, Fundamentals of Clin Chem. Young DS, Naito HK et al. 1973;10:79.

15. Buccolo G, David M. Clin Chem. 1973;19(5):476-82.

16. Ray D, Shartchandra KH, Thokchom IS. Antipyretic, Antidiarrhoeal, Hypoglycaemic and Hepatoprotective activities of ethyl acetate extract of Acacia catechu wild in albino rats. Ind J Pharmacol. 2006;38(6):408-13. http://dx.doi. org/10.4103/0253-7613.28207

17. Seifert WF, Bosma A, Brouwer A; Bosma; Brouwer; Hendriks; Rololl Van Leeuwen; Van Thiel-Deruiter; Seifert-Bock; Knook et al. Vitamin-A deficiency potentiates carbon tetrachloride-induced liver fibrosis in rats. Hepatology. 1994;19(1):193-201.

18. Hinson JA. Pahl. Monks, Gillet JR. Acetiminophen induced hepatotoxicity. Life sci. 1981;29:107-116. http://dx.doi.org/10.1016/0024-3205(81)90278-2.

19. Preseott LF, Wringht N, Roseo P, Brown SS. Plasma paracetamol half life and hepatic necrosis in patients with paracetamol 120 overdose. Lancet. l;13;297(7698):519-22

20. Sharma A. Chakraborti KK, Handa SS. Anti-hepatotoxic activity of some Indian herbal formulation as compare to Silymarin. Fitoterapia. 1991;62:299-35.

Cite this Article: In-vivo hepatoprotective activity of methanolic extracts of Sphaeranthus amaranthoides and Oldenlandia umbellate. Somnath D, Suresh R, Babu AKMSS, Aneela S. Pharmacogn J. 2017;9(1):98-101 